\title{
Hyperforin Induces Apoptosis Through Extrinsic/Intrinsic Pathways and Inhibits NF-kB-modulated Survival and Invasion Potential in Bladder Cancer
}

\author{
YU-CHANG LIU ${ }^{1,2,3^{*}}$, KUANG-HSUAN LIN ${ }^{3 *}$, JUNG-HUNG HSIEH ${ }^{4}$, JING-GUNG CHUNG ${ }^{5,6}$, \\ ZHAO-LIN TAN ${ }^{1,6}$, FEI-TING HSU ${ }^{6}$ and CHIH-HUNG CHIANG ${ }^{4,7,8}$ \\ ${ }^{1}$ Department of Medical Imaging and Radiological Sciences, \\ Central Taiwan University of Science and Technology, Taichung, Taiwan, R.O.C.; \\ ${ }^{2}$ Department of Radiation Oncology, Show Chwan Memorial Hospital, Changhua, Taiwan, R.O.C.; \\ ${ }^{3}$ Department of Radiation Oncology, Chang Bing Show Chwan Memorial Hospital, Changhua, Taiwan, R.O.C.; \\ ${ }^{4}$ Department of Urology, Medical Research and Education, \\ Taipei Veterans General Hospital, Yuan-Shan/Su-Ao Branch, Yilan, Taiwan, R.O.C.; \\ ${ }^{5}$ Department of Biotechnology, Asia University, Taichung, Taiwan, R.O.C.; \\ ${ }^{6}$ Department of Biological Science and Technology, China Medical University, Taichung, Taiwan, R.O.C.; \\ ${ }^{7}$ Department of Nursing, Cardinal Tien Junior College of Healthcare and Management, New Taipei, Taiwan, R.O.C.; \\ ${ }^{8}$ Department of Urology, National Taiwan University Hospital, Taipei, Taiwan, R.O.C.
}

\begin{abstract}
Background/Aim: Muscle-invasive bladder cancer $(M I B C)$ has long been recognized as a difficult to treat cancer type, thus a new treatment strategy is needed. The major purpose of the present study was to verify the anticancer effect of hyperforin and the mechanism through which it affects tumor cell growth and invasion in bladder cancer in vitro. Materials and Methods: Bladder cancer TSGH-8301 cells were treated with different concentrations of hyperforin for different durations of time. The changes in cell viability, production of calcium and reactive oxygen species (ROS), and anti-apoptotic signaling were evaluated using MTT assay, flow cytometry, and western blot analysis. The effect of hyperforin on the expression of nuclear factor-kappaB (NF-kB) p65 (Ser276), tumor progression-associated proteins, as well as on cell invasion was investigated using western blotting and cell invasion assay, respectively. Results: Hyperforin significantly induces apoptosis, extrinsic/intrinsic apoptotic signaling,
\end{abstract}

This article is freely accessible online.

*These Authors contributed equally to this study.

Correspondence to: Chih-Hung Chiang, Department of Urology, Medical Research and Education, Taipei Veterans General Hospital, Yuan-Shan/Su-Ao Branch, Yilan 264, Taiwan, R.O.C. Tel: +886 936-701-173, e-mail: guchiang@gmail.com

key Words: Hyperforin, bladder cancer, NF-KB, p65, calcium signalling, cytosol ROS, apoptosis. accumulation of cytosol ROS, and calcium signalling. Hyperforin also significantly diminishes the expression of $N F$ ${ }_{k B}$ p65 (Ser276), anti-apoptotic and tumor progressionassociated proteins, as well as the cell invasion ability of TSGH-8301 cells. Conclusion: Our findings demonstrate that hyperforin triggers apoptosis depending on extrinsic/intrinsic pathways and suppresses $\mathrm{NF}-\mathrm{kB}$-mediated cell survival as well as the invasive properties of bladder cancer in vitro.

Based on the depth of tumor invasion within the bladder wall, bladder cancer is divided into two types: i) muscle invasive bladder cancer (MIBC) and ii) non- muscle invasive bladder cancer (NMIBC) (1). MIBC patients have a poor survival compared to NMIBC patients. Patients with MIBC do not respond to current treatment options and no more effective treatment strategies have appeared in the past decades $(2,3)$. The development of potential therapeutic agents could offer benefits for MIBC patients.

Herbal medicines, compounds and composite formulas extracted from natural plants, have been indicated as preventive or therapeutic agents for bladder cancer. Dietary intakes of flavonol and lignans, multifunctional compounds of plants, have been presented to reduce bladder cancer risk (4). Lee et al., have demonstrated the therapeutic efficacy of herbal medicines in a 74-year-old Korean patient with metastatic bladder cancer, where his pulmonary metastasis was diminished following his herbal treatment (5).

Hyperforin, a bioactive compound extracted from medicinal plant St. John's wort (SJW), has been recognized 
as a conventional antidepressant by suppressing the uptake of serotonin, norepinephrine dopamine, $\gamma$-aminobutyric acid (GABA), and L-glutamate (6). In addition, hyperforin can also inhibit tumor cell growth and invasion ability in hepatocellular carcinoma (HCC) and lung cancer $(7,8)$. However, whether hyperforin modulates inhibition of tumor cell growth and invasive potential in bladder cancer is ambiguous. Therefore, the aim of the present study was to verify the anti-cancer effect and elucidate the mechanism of hyperforin's action on tumor cell growth and invasion in an in vitro model of bladder cancer.

\section{Materials and Methods}

Reagents, commercial kits and antibodies. Hyperforin, dimethyl sulfoxide (DMSO), Triton X and MTT (3-(4,5-Dimethylthiazol-2yl-2,5- Diphenyltetrazolium Bromide)) were obtained from SigmaAldrich Corp. (St. Louis, MO, USA). RPMI 1640, fetal bovine serum (FBS), L-glutamine and penicillin-streptomycin were all obtained from GIBCO/Invitrogen Life Technologies (Carlsbad, CA, USA). Flow cytometry related dyes were listed and purchased from relative companies as followed. Propidium iodide (PI) (9), CaspGLOW $^{\mathrm{TM}}$ Fluorescein Active Caspase-3 Staining Kit, and CaspGLOW ${ }^{\mathrm{TM}}$ Red Active Caspase-8 Staining Kit were acquired from Biovision (Mountain View, CA, USA). RNase was bought from Fermentas (St. Leon-Rot, Baden-Wurttemberg, Germany). Annexin VFITC apoptosis detection kit was purchased from Vazyme Biotech Co. Lt (Nanjing City, China). PE-conjugatedantiCD178 (FAS-L) antibody, FITC-conjugated anti-CD95 (FAS) antibody and cleaved PARP1-FITC were all purchased from BioLegend, (San Diego, CA, USA) and Thermo Fisher Scientific (Fremont, CA, USA), respectively. Migration assay transwell $(8-\mu \mathrm{m}$ pore size) were purchased from Corning Life Sciences (Tewksbury, MA, USA). Western blot assay related primary antibodies: cellular FLICE (FADD-like IL $1 \beta$-converting enzyme)-inhibitory protein (CFLIP, Cell Signaling Technology, Inc., Danvers, MA, USA), Xlinked inhibitor of apoptosis protein (XIAP, Thermo Fisher Scientific), myeloid leukemia cell differentiation protein (MCL1, BioVision), matrix metallopeptidase 9 (MMP9, EMD Millipore, Billerica, MA, USA), vascular endothelial growth factor (VEGF, EMD Millipore), Cyclin D1 (Thermo Fisher Scientific), Phosphop65 NF-kB (Ser276) (Signalway Antibody LLC, MD, USA), p65 NF-kB antibody (Abcam, Canary Wharf, London, UK) , $\beta$-actin (Santa Cruz, CA, USA) and TBP (Abcam). Secondary antibodies were purchased from Jackson ImmunoResearch (West Grove, PA, USA).

Cell culture. The TSGH-8301 human bladder carcinoma cell line was kindly provided from Professor Jing-Gung Chung's lab, China Medical University. Cells were placed into $10 \mathrm{~cm}$ culture plate and grown at $37^{\circ} \mathrm{C}$ under a humidified $5 \% \mathrm{CO}_{2}$ atmosphere in RPMI1640 medium with $2 \mathrm{mM}$ L-glutamine, $10 \% \mathrm{FBS}, 100 \mathrm{Units} / \mathrm{ml}$ penicillin, and $100 \mu \mathrm{g} / \mathrm{ml}$ streptomycin (10).

Cell viability assays. TSGH-8301 cells were seeded in a 96-well plate at a density of $3 \times 10^{4}$ cells/well and were incubated overnight. Subsequently, they were treated with hyperforin at $0,5,10,20$ and $30 \mu \mathrm{M}$ for 24 or $48 \mathrm{~h}$. Cells were stained using MTT 3-(4,5- dimethylthiazol-2-yl) -2,5-diphenyltetrazolium bromide for another 4 $\mathrm{h}$ following the treatment. Finally, the percentage of viable cells was analyzed using by a spectrophotometer at $570 \mathrm{~nm}$ wavelength (Tecan Group Ltd., Männedorf, Switzerland) as previously described (11).

Annexin-V/PI, cleaved caspase-3, subG1 accumulation staining. First, $5 \times 10^{5}$ cells/well of TSGH-8301 cells in 6 -well plates were incubated with 0,10 and $20 \mu \mathrm{M}$ of hyperforin for $48 \mathrm{~h}$. The cells were then trypsinized, harvested, stained with Annexin V/PI or cleaved caspase- 3 dye in a dark room for 30 minutes at $37^{\circ} \mathrm{C}$ and were analyzed by flow cytometry for apoptotic cell population determination, as described previously (10). For subG1 analysis, cells were trypsinized, harvested, fixed by $75 \%$ ethanol overnight at $-20^{\circ} \mathrm{C}$, stained by PI solution (for cell cycle analysis, $40 \mu \mathrm{g} / \mathrm{ml}$ PI, $100 \mu \mathrm{g} / \mathrm{ml}$ RNase and $1 \%$ Triton X-100 in PBS) for $30 \mathrm{~min}$ at $37^{\circ} \mathrm{C}$ and analyzed by flow cytometry (8). The results of the staining were measured using the FlowJo 7.6.1 software (FlowJo LLC, Ashland, OR, USA).

Extrinsic apoptosis analysis. Approximately $5 \times 10^{5}$ cells/well of TSGH-8301 cells in 6-well plates were incubated with 0,10 and 20 $\mu \mathrm{M}$ of hyperforin for $48 \mathrm{~h}$. The cells were trypsinized, harvested, and stained with FAS, FASL and cleaved caspase-8, as described in previous studies $(12,13)$. The results of above staining were measured using the FlowJo 7.6.1 software.

Intrinsic apoptosis analysis. Approximately $5 \times 10^{5}$ cells/well of TSGH-8301 cells in 6-well plates were incubated with 0,10 and 20 $\mu \mathrm{M}$ of hyperforin for $48 \mathrm{~h}$. The cells were trypsinized, harvested, and were stained with Fluo-3/AM $(2.5 \mu \mathrm{g} / \mathrm{ml})$ and $500 \mu \mathrm{L}$ of $\mathrm{DiOC}_{6}$ ( $4 \mu \mathrm{mol} / \mathrm{l}$ ) for 30 minutes to measure the changes of intracellular $\mathrm{Ca}^{2+}$ level, and mitochondrial membrane potential $(\Delta \Psi \mathrm{m})$ levels, respectively. The results of above staining were measured using the FlowJo 7.6.1 software (13).

Measurements of reactive oxygen species (ROS). TSGH-8301 cells $\left(5 \times 10^{5}\right.$ cells/well) were treated with 0,10 and $20 \mu \mathrm{M}$ of hyperforin for $48 \mathrm{~h}$. Following incubation, cells were harvested and resuspended in $500 \mu \mathrm{l}$ of DCFH-DA $(10 \mu \mathrm{M})$ for $1 \mathrm{~h}$ to measure the changes of ROS. All samples were analyzed by flow cytometry and measured using the FlowJo 7.6.1 software as described (14).

Western blotting. About $3 \times 10^{6}$ cells TSGH-8301 cells were incubated in a $100-\mathrm{mm}$ culture dishes overnight and were then treated with 0,10 and $20 \mu \mathrm{M}$ of hyperforin for $48 \mathrm{~h}$. Nuclear and cytosol extracts were prepared using a Nuclear/Cytosol fractionation kit (BioVision, Milpitas, CA, USA), according to the manufacturer's protocol. Briefly, appropriate buffers of the kit were used to extract the cytosolic or nuclear fractions and separated by centrifugation. Proteins extracted from cells were then separated by SDS polyacrylamide gels, electrotransfered onto PVDF membrane (EMD Millipore), incubated with primary antibodies, and followed by secondary antibody incubation. The immunoreactive bands were then visualized using the Immobilon Western Chemiluminescent HRP Substrate kit (EMD Millipore) and were detected using a chemiluminescent image system (ChemiDoc-It 515, UVP) $(10,13)$. Invasion assay. TSGH-8301 cells were seeded into $10 \mathrm{~cm}$ diameter dishes at $3 \times 10^{6}$ cells, incubated overnight, and were then treated with 0,10 or $20 \mu \mathrm{M}$ hyperforin for $48 \mathrm{~h}$. Then, cells were collected for transwell migration assay, as described in previous studies (15). 


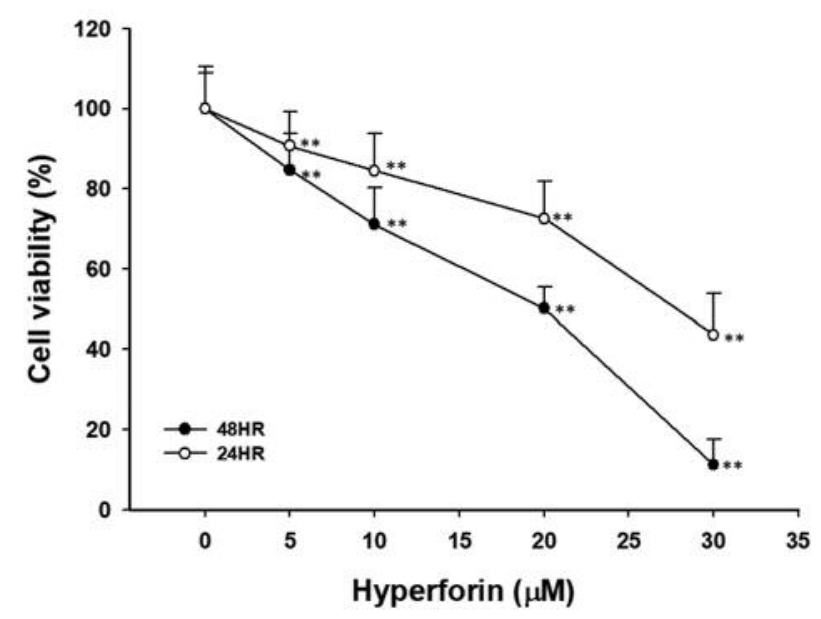

Figure 1. Hyperforin reduces the percentage of total viable TSGH-8301 cells. TSGH-8301 cells were treated with 0-30 $\mu \mathrm{M}$ of hyperforin for 24 and $48 \mathrm{~h}$. Cell viability was then assayed by the MTT assay $\left({ }^{* *} p<0.01\right.$; treatments versus $0 \mu M$ hyperforin).

Statistical analysis. We expressed all data as mean \pm standard deviation. The difference between the $0 \mu \mathrm{M}$, and hyperforin $10 \mu \mathrm{M}$ or $20 \mu \mathrm{M}$ were analyzed using the Student's $t$-test, with a probability of $p<0.05$ considered significant.

\section{Results}

Effects of hyperforin on viability of TSGH-8301 cells. In order to examine the effects of hyperforin on the viable TSGH-8301 cells, the latter were treated with various doses of hyperforin (from 0-30 $\mu \mathrm{M}$ ) for 24 and $48 \mathrm{~h}$. The percentage of viable cells was measured using the MTT assay, as shown in Figure 1. The results indicate that hyperforin-induced cytotoxicity occurs in a dose dependent manner (Figure 1) and decreases the percentage of viable cells by about $30-50 \%$ at a treatment between $10-20 \mu \mathrm{M}$ of hyperforin. These effects are both dose and time dependent.

Effects of hyperforin on apoptosis were examined by AnnexinV/PI, cleaved caspase-3, subG1 accumulation staining and anti-apoptosis factors levels in TSGH-8301 cells. When compared to the control sample, hyperforin markedly induced Annexin-V and PI population (Figure 2A). Also, cleaved caspase-3 was activated by hyperforin in a dose dependent manner in TSGH-8301 cells (Figure 2B). Flow cytometry analysis showed that the sub- $\mathrm{G}_{1}$ population (Figure $2 \mathrm{C}$ ) present in TSGH-8301 cells following exposure to hyperforin corresponded to Annexin-V and cleaved caspase-3 activation. To confirm apoptotic cell death, we evaluated whether antiapoptosis related factors (C-FLIP, XIAP and MCL-1) expression was also blocked by hyperforin (Figure 2D). Taken together, we concluded that hyperforin decreased the expression level of anti-apoptosis factors in TSGH-8301 cells and increased the induction of apoptotic death.

Effects of hyperforin on the activities of extrinsic apoptosis pathway in TSGH-8301 cells. To investigate whether death receptor-mediated apoptosis is involved in hyperforininduced apoptosis, the activity of FAS, FASL and cleaved caspase- 8 were detected using flow cytometry. The results presented in Figure 3A-C indicate the hyperforin-induced a rapid rise in FAS, FASL and cleaved caspase- 8 activities. Importantly, cleaved caspase- 8 was required for the signaling transduction of Fas-FasL mediated extrinsic apoptosis pathway. As such, we suggest that hyperforin-provoked apoptosis is achieved through at least one death receptordependent extrinsic apoptosis pathway in TSGH-8301 cells.

Effects of hyperforin on the activities of intrinsic apoptosis pathway in TSGH-8301 cells. In order to investigate whether mitochondria-dependent apoptosis is involved in hyperforininduced cell death, the release of calcium iron $\left(\mathrm{Ca}^{2+}\right)$ and the change of mitochondrial membrane potential were measured using flow cytometry. Results are shown in Figure 4A, indicating a release of $\mathrm{Ca}^{2+}$ in hyperforin treated cells. Additionally, hyperforin significantly decreased the $\Delta \Psi_{\mathrm{m}}$ in TSGH-8301 cells (Figure 4B). Based on these observations, the loss of $\Delta \Psi \mathrm{m}$ involved intracellular $\mathrm{Ca}^{2+}$ following exposure to hyperforin and it affects cell viability in TSGH8301 cells. Therefore, we suggested that intracellular $\mathrm{Ca}^{2+}$ might play a vital factor in hyperforin-induced intrinsic apoptosis in TSGH-8301 cells.

Effects of hyperforin on the production of ROS and cleaved PARP-1 in TSGH-8301 cells. In order to investigate whether hyperforin-induced apoptosis is associated with ER stressinduced cell death mechanisms we further investigated the production of ROS using flow cytometry. As showed in Figure 5A, the production of ROS increased in hyperforintreated TSGH-8301 cells. Furthermore, the cleaved PARP-1 mediated DNA damage was also triggered via the accumulation of ROS in TSGH-8301 cells by hyperforin (Figure 5B). Hyperforin induced the production of reactive oxygen species (ROS) acted as a trigger point of further apoptosis signal transduction.

Effects of hyperforin on the inhibition of invasion and tumor progression in TSGH-8301 cells via blockage of $\mathrm{NF}-\mathrm{kB}$ signal transduction. To determine the degree of inhibition of hyperforin on TSGH-8301 cells invasion, we performed a transwell cell invasion. The number of invasion cells in the transwell membranes were counted and photographed. We found that hyperforin significantly inhibited cell invasion by $80 \%-90 \%$ on 10 and $20 \mu \mathrm{M}$ hyperforin at $48 \mathrm{~h}$ as compared 
A

Hyperforin $(\mu \mathrm{M})$
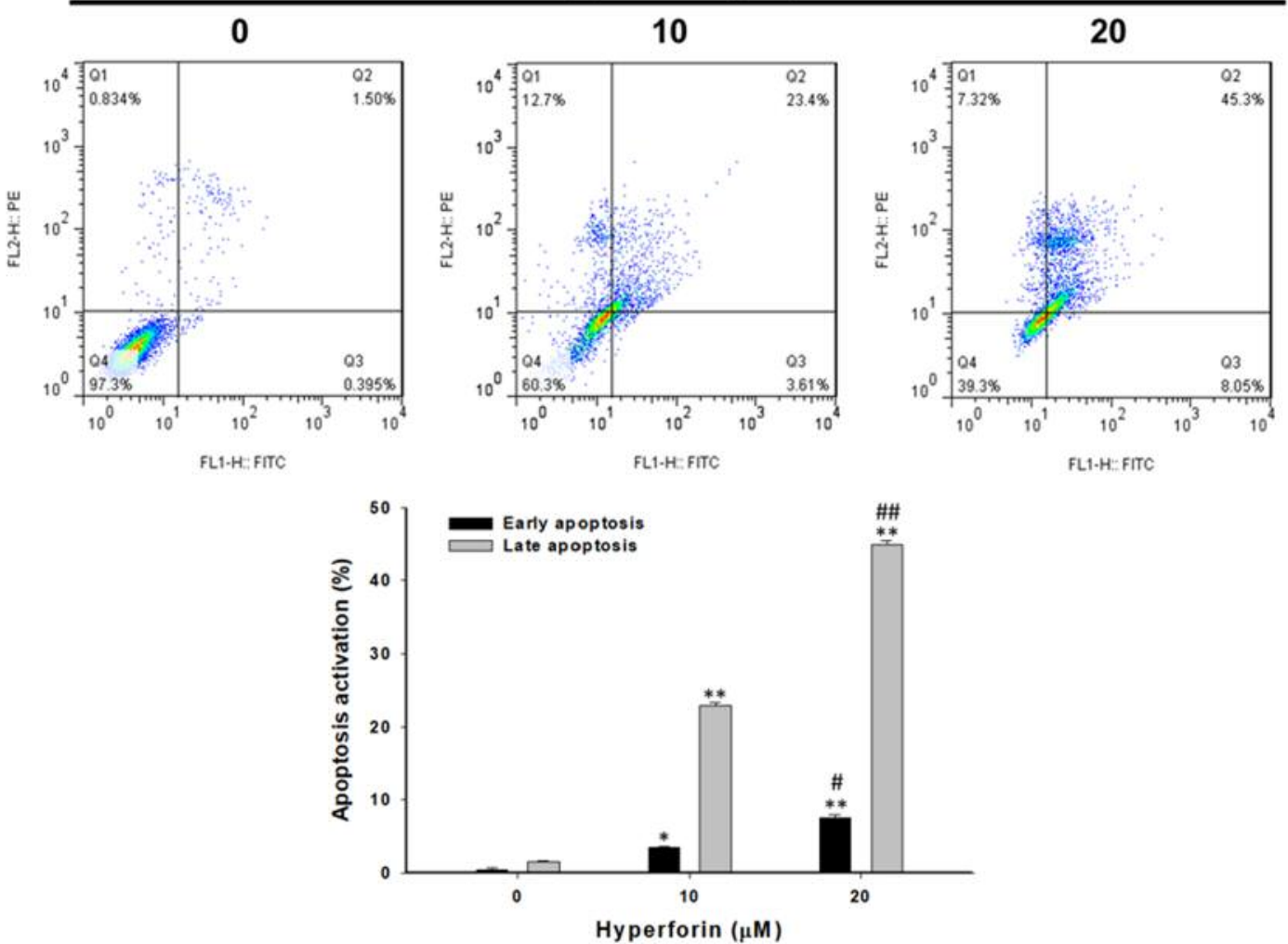

B

Hyperforin $(\mu \mathrm{M})$
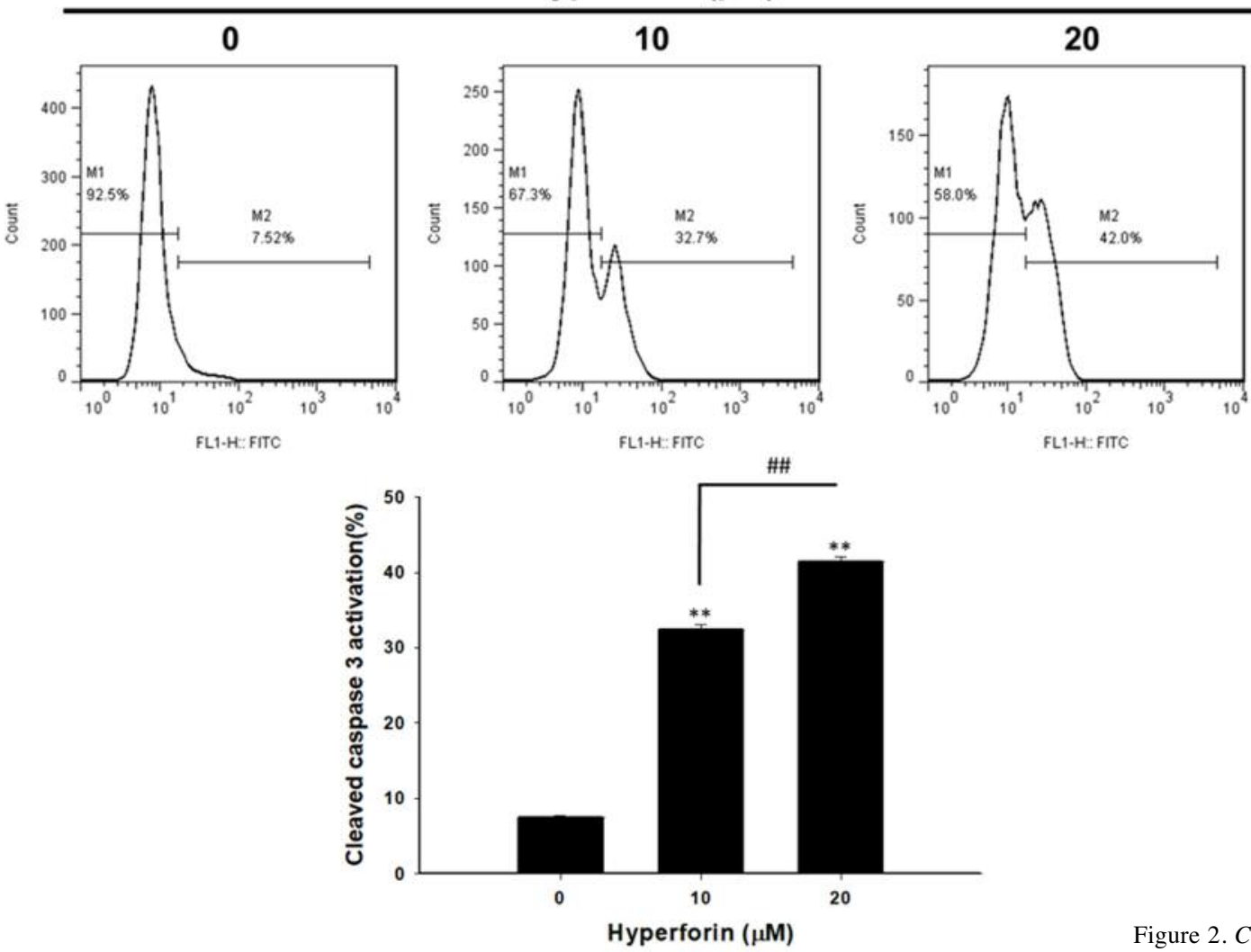

Figure 2. Continued 
C
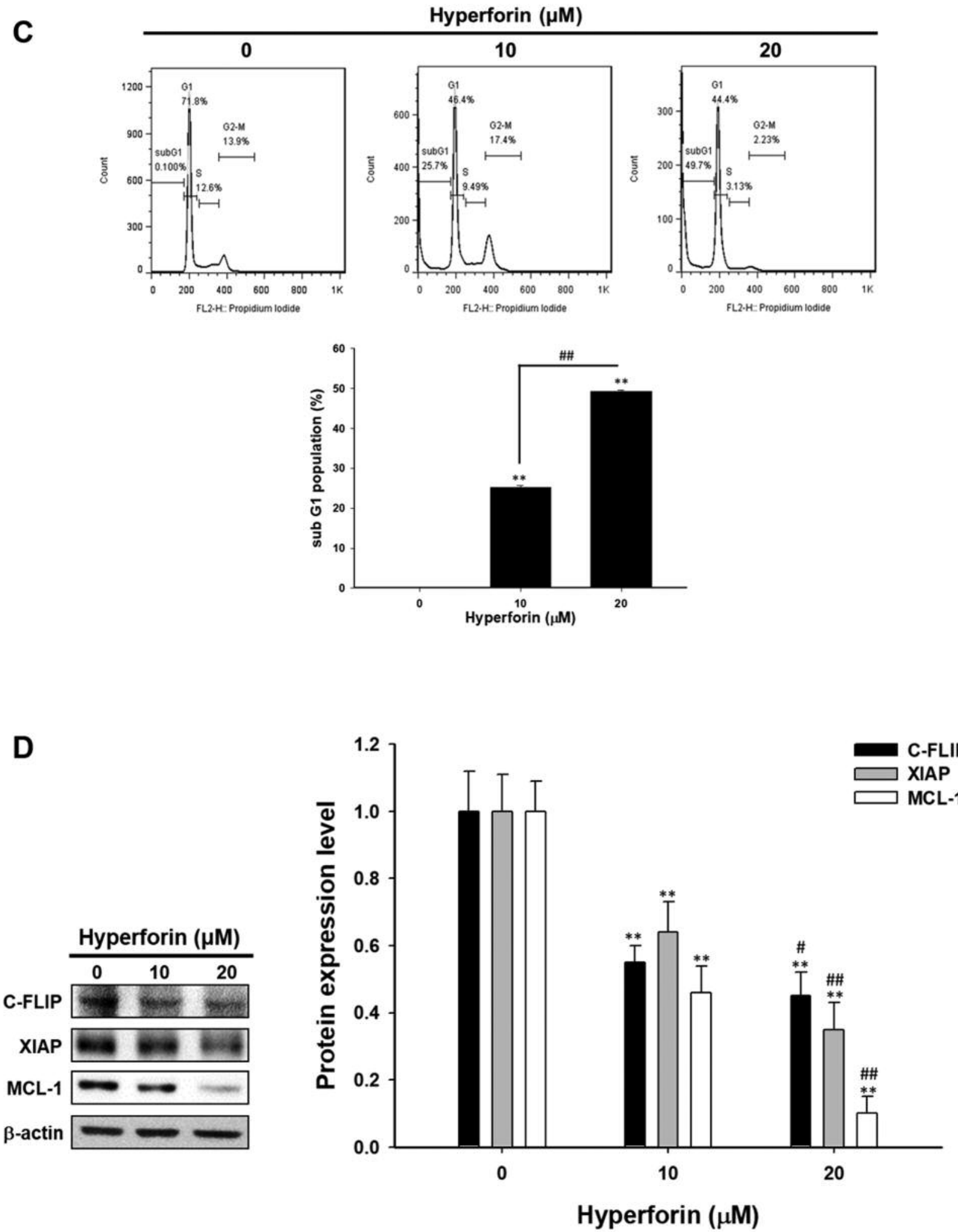

Figure 2. Hyperforin triggers apoptosis. TSGH-8301 cells were treated with 0, 10 and $20 \mu \mathrm{M}$ of hyperforin for $48 \mathrm{~h}$. Cells were then collected, stained for (A-C), Annexin-V/PI cleaved caspase-3 and PI dye for apoptosis analysis, respectively, and were assayed by flow cytometry. (D) The protein expression of C-FLIP, XIAP and MCL-1 was assayed by Western blot $\left({ }^{*} p<0.05,{ }^{* *} p<0.01\right.$; treatments versus $0 \mu M$ hyperforin; ${ }^{\#} p<0.05$, $\#$ \# $<0.01$; treatments versus $10 \mu M$ hyperforin). 
A

Hyperforin $(\mu \mathrm{M})$

A
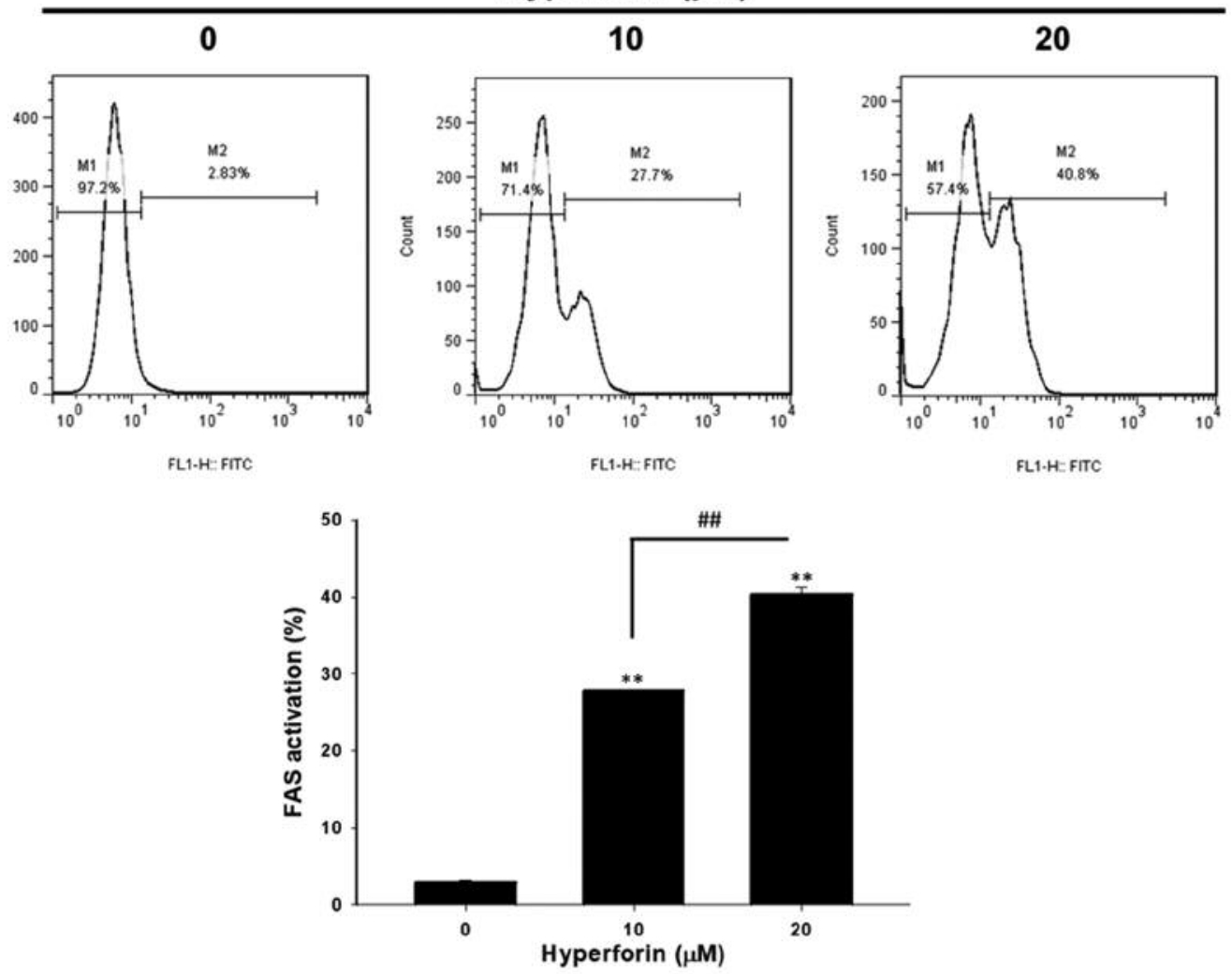

B

Hyperforin ( $\mu \mathrm{M})$
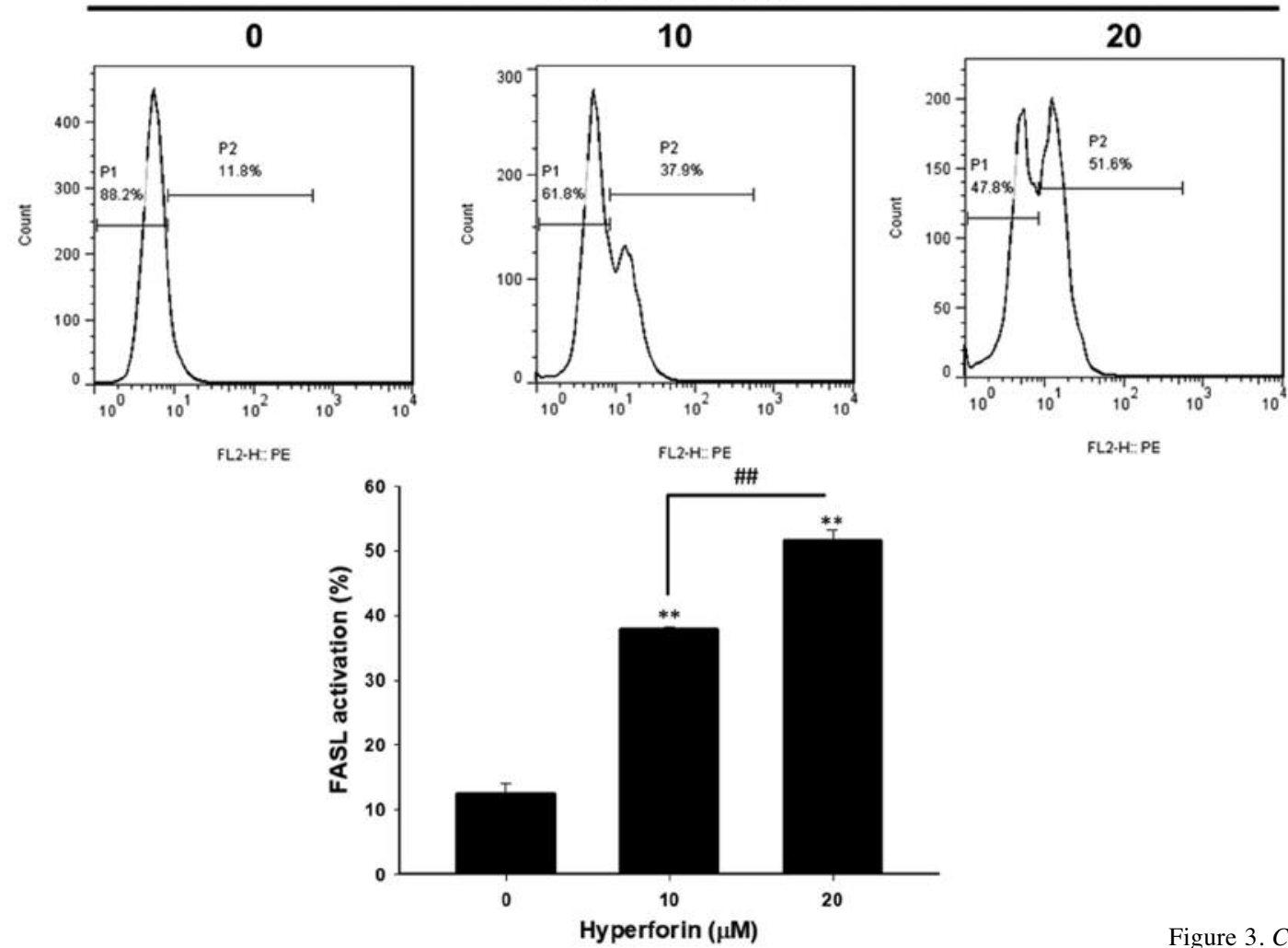

Figure 3. Continued 


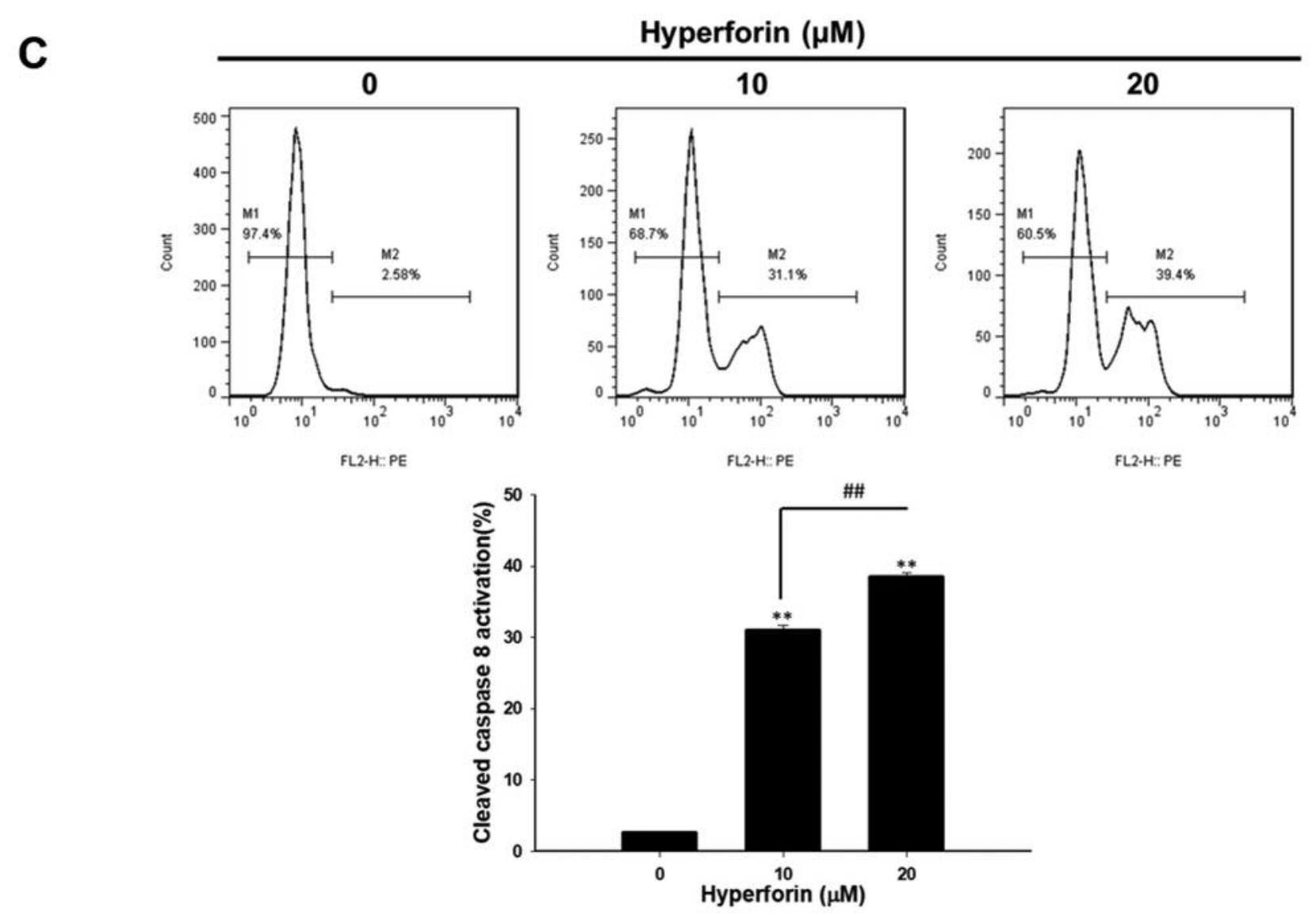

Figure 3. Hyperforin activates extrinsic FAS, FASL and cleaved caspase-8 signaling in TSGH-8301 cells. TSGH-8301 cells were treated with 0 , 10 and $20 \mu \mathrm{M}$ of hyperforin for $48 \mathrm{~h}(\mathrm{~A}-\mathrm{C})$. Cells were then collected, stained for FAS, FASL and cleaved caspase-3, respectively, and were assayed by flow cytometry $\left({ }^{* *} p<0.01\right.$; treatments versus $0 \mu M$ hyperforin; ${ }^{\# \#} p<0.01$; treatments versus $10 \mu M$ hyperforin).

to control cells (Figures 6A). Then, we investigated whether hyperforin may also suppress the expression of other proteins that may affect tumor invasion ability. As showed in Figure $6 \mathrm{~B}$, both matrix metallopeptidase 9 (MMP-9) and vascular endothelial growth factor (VEGF) protein levels were reduced following hyperforin treatment. Furthermore, the expression of the tumor proliferation factor, cyclinD1, was also suppressed by hyperforin (Figure 6B). Finally, we also found that hyperforin may be involved in the dephosphorylation of NF-kB (Figure 6C). Taken together, our data suggest that hyperforin may suppress tumor progression via inactivation of the NF-kB signal transduction pathway.

\section{Discussion}

Cyclin-D1, VEGF, and MMP-9 as tumor progressionassociated proteins promote tumor progression through induction of cell proliferation, angiogenesis, and metastasis $(10,16)$. Overexpression of cyclin-D1, VEGF, and MMP-9 are unfavorable prognostic markers that can contribute to tumor recurrence and invasion and are correlated with poor survival in patients with MIBC, whereas their inhibition abolishes tumor cell growth and invasion ability in bladder cancer $(9,17,18)$. Our data showed that hyperforin significantly suppresses the protein levels of Cyclin-D1, VEGF, and MMP-9 in TSGH-8301 cells as well as their invasive properties.

Apoptosis, programmed cell death, prevents tumor formation, however, anti-apoptotic proteins present in tumor cells disrupt extrinsic and intrinsic apoptotic pathways, resulting in evasion of apoptosis and promotion of tumor cell survival $(19,20)$. Cisplatin is an anticancer agent that induces apoptosis by deoxyribonucleic acid (DNA) damage and is used for the treatment of bladder cancer (21). Anti-apoptotic proteins mediate an acquired resistance to cisplatin in bladder cancer $(21,22)$. In our results presented here, hyperforin significantly suppressed the expression of anti-apoptotic proteins C-FLIP, XIAP, and MCL-1 in TSGH-8301 cells.

Expression of tumor suppressor proteins that restrict cell cycle progression and cell survival is inhibited in bladder 
A
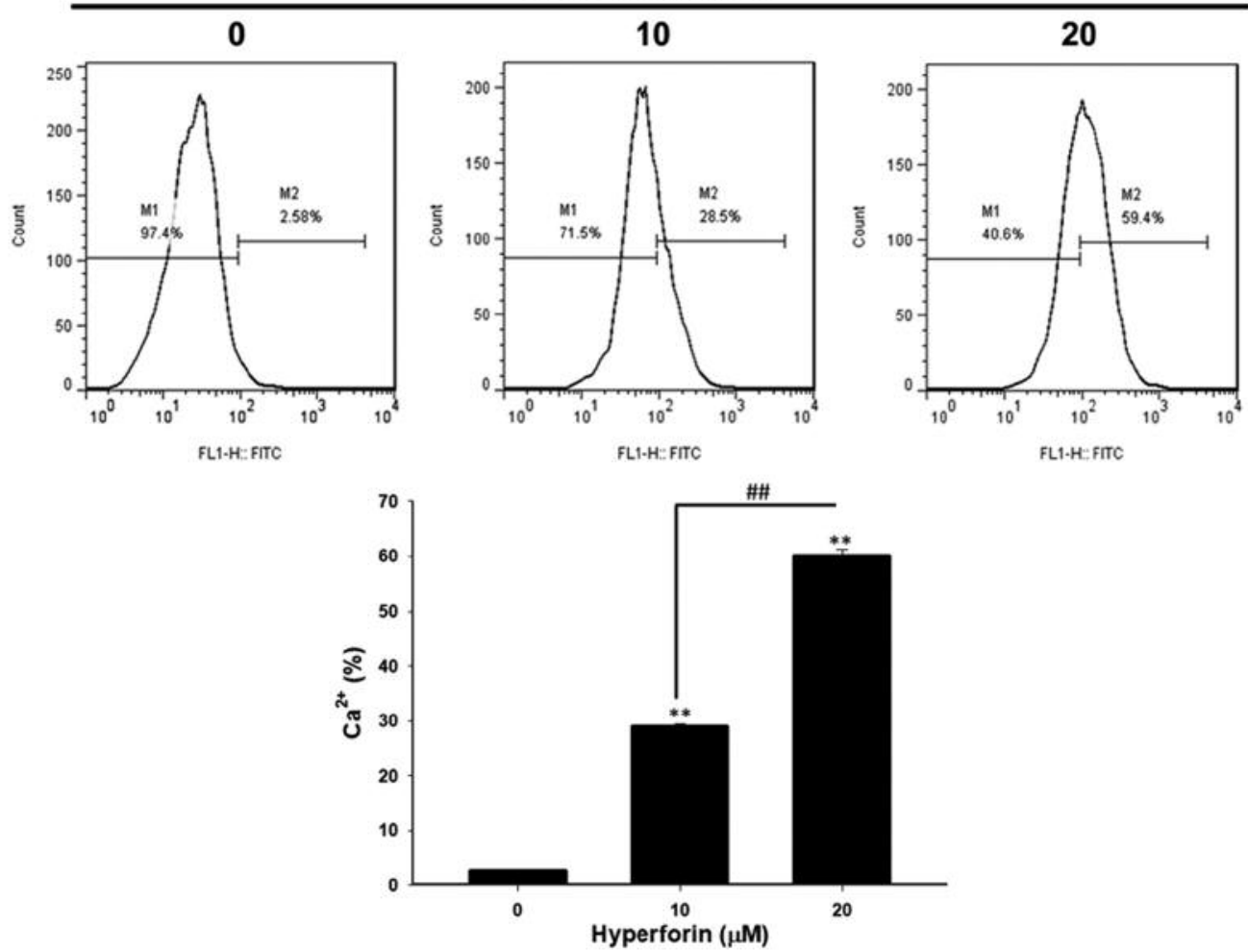

B

Hyperforin $(\mu \mathrm{M})$
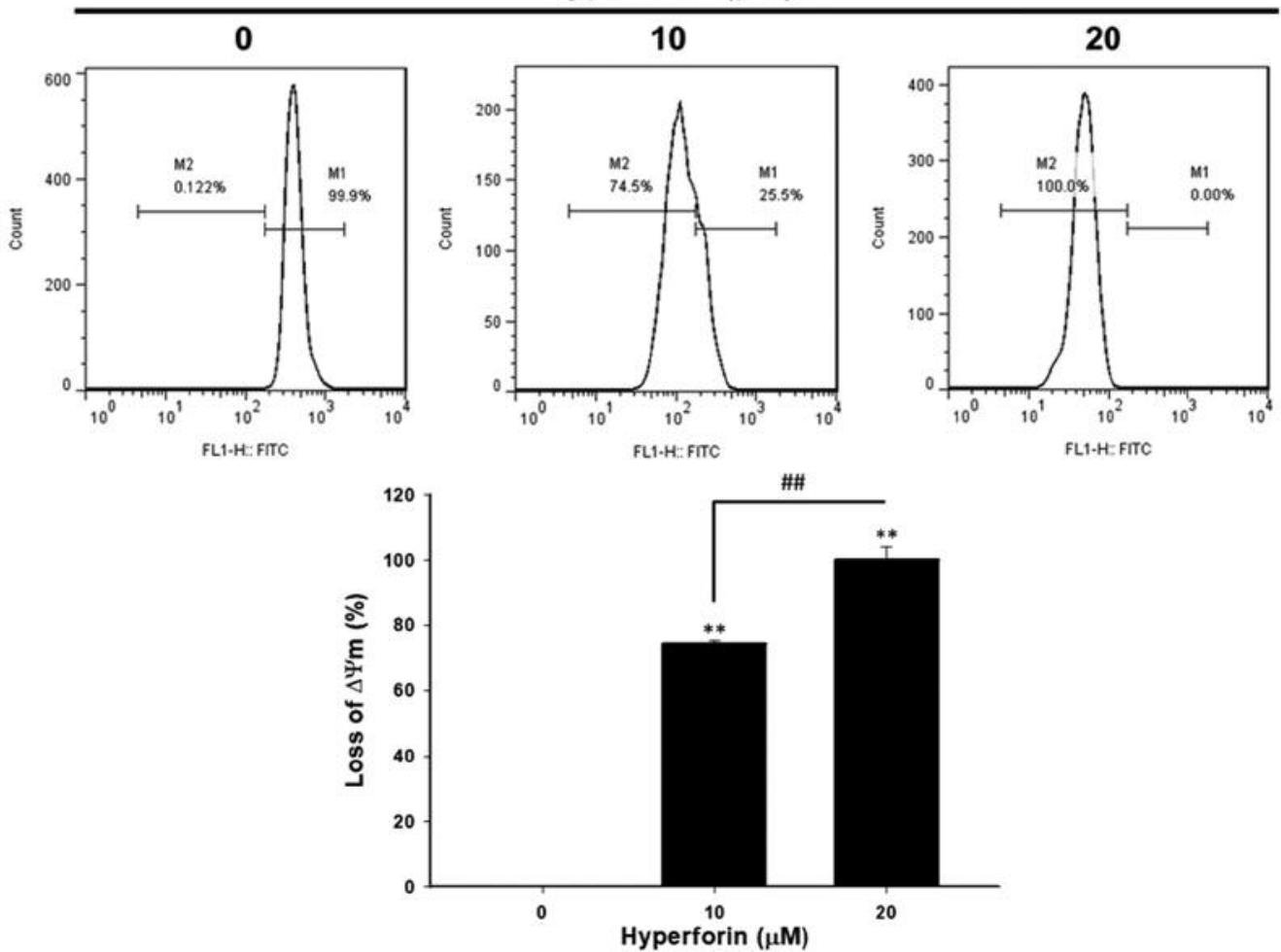

Figure 4. Hyperforin induces the release of calcium iron $\left(\mathrm{Ca}^{2+}\right)$ and the loss of mitochondrial membrane potential ( $\left.4 \Psi m\right)$ in TSGH-8301 cells. TSGH-8301 cells were treated with 0,10 and $20 \mu \mathrm{M}$ of hyperforin for $48 \mathrm{~h}$. Cells were then collected, stained for $(A) \mathrm{Ca}^{2+}$ and $(B) \mathrm{DIOC}_{6}$ for mitochondrial membrane potential, respectively, and were assayed by flow cytometry (**p<0.01; treatments versus $0 \mu M$ hyperforin; \#\# $<0.01$ treatments versus $10 \mu M$ hyperforin). 
A

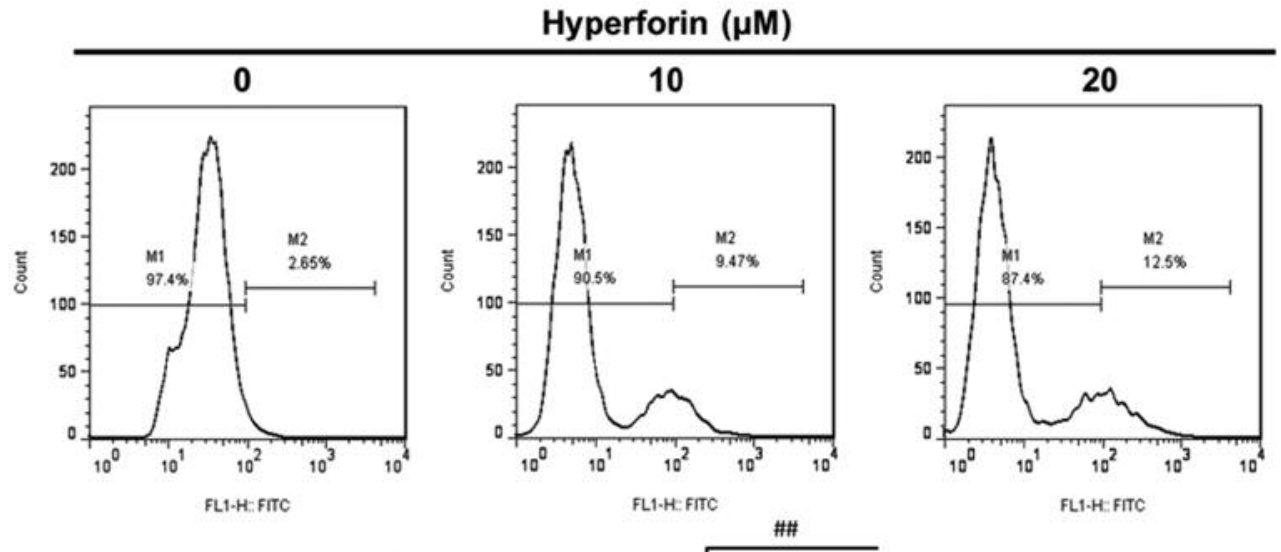

B

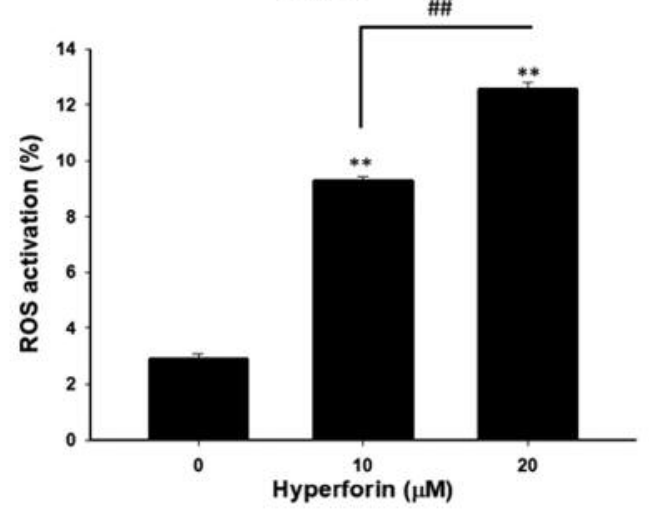

Hyperforin $(\mu \mathrm{M})$
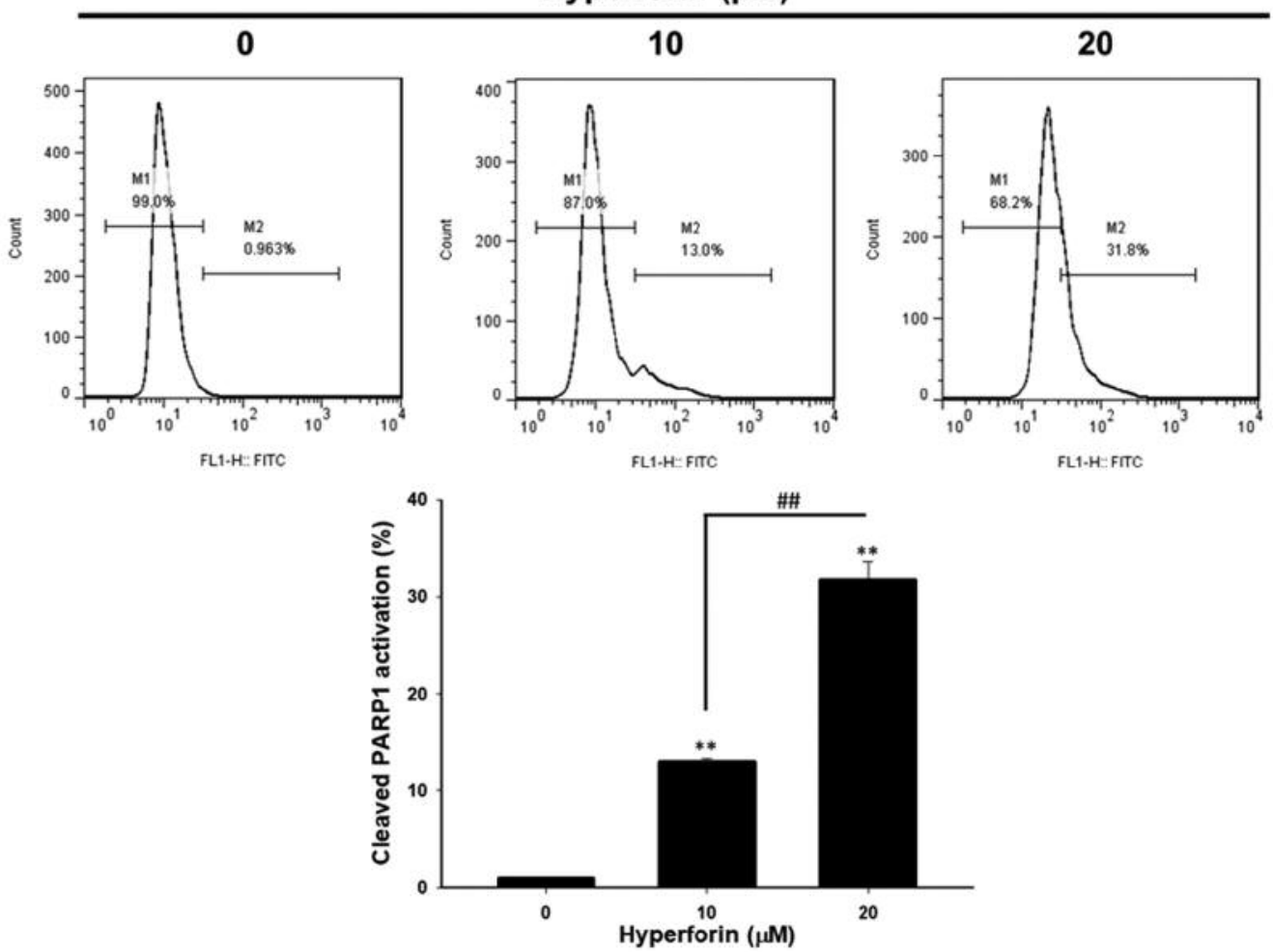

Figure 5. Hyperforin induces the production of ROS and cleaved PARP-1 in TSGH-8301 cells. TSGH-8301 cells were treated with 0, 10 and $20 \mu M$ of hyperforin for $48 \mathrm{~h}$. Cells were subsequently collected, stained for (A) ROS and (B) cleaved PARP-1, respectively, and were assayed by flow cytometry $\left({ }^{* *} p<0.01\right.$; treatments versus $0 \mu M$ hyperforin; ${ }^{*} p<0.01$; treatments versus $10 \mu M$ hyperforin). 
A

Hyperforin $(\mu \mathrm{M})$
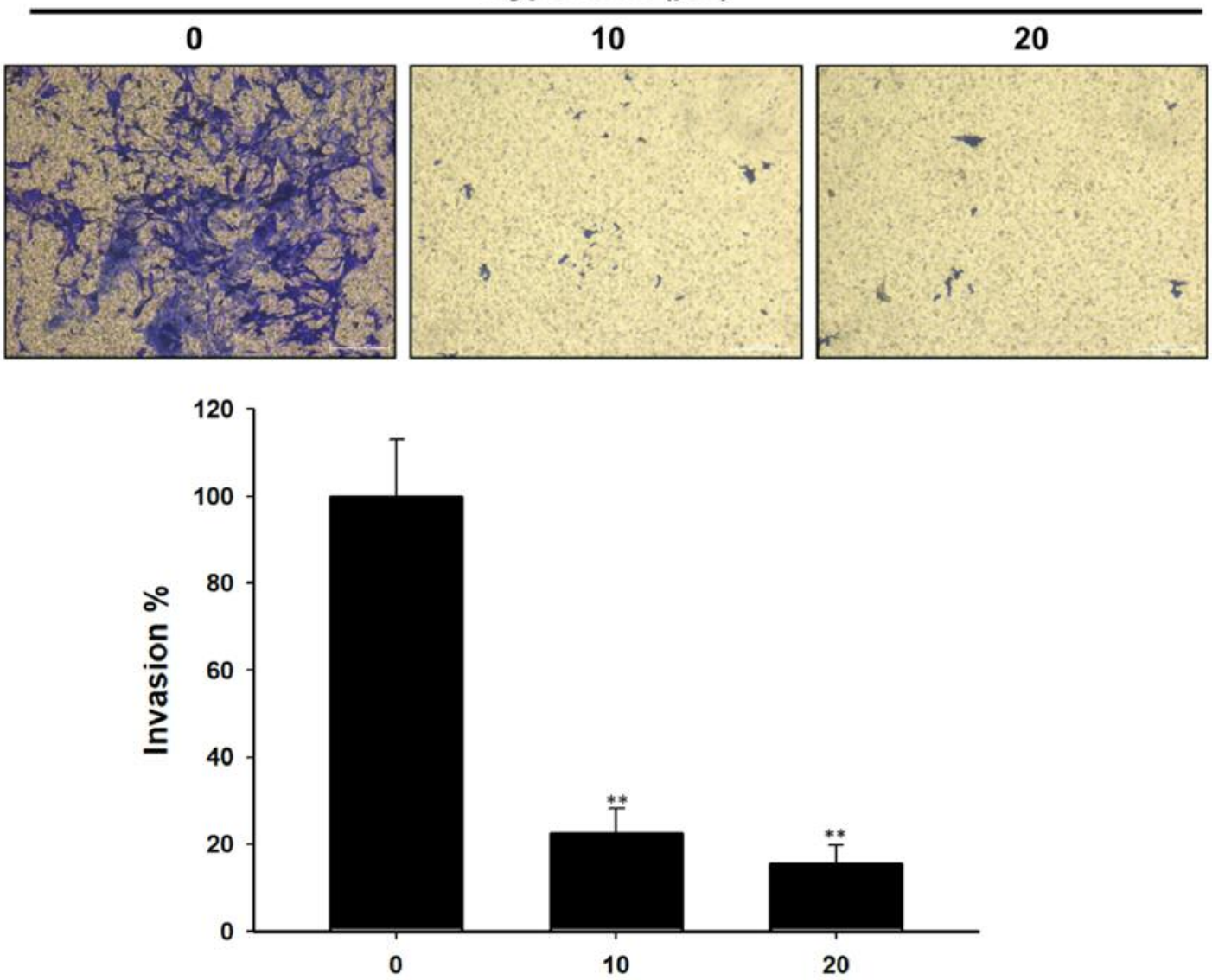

Hyperforin $(\mu \mathrm{M})$
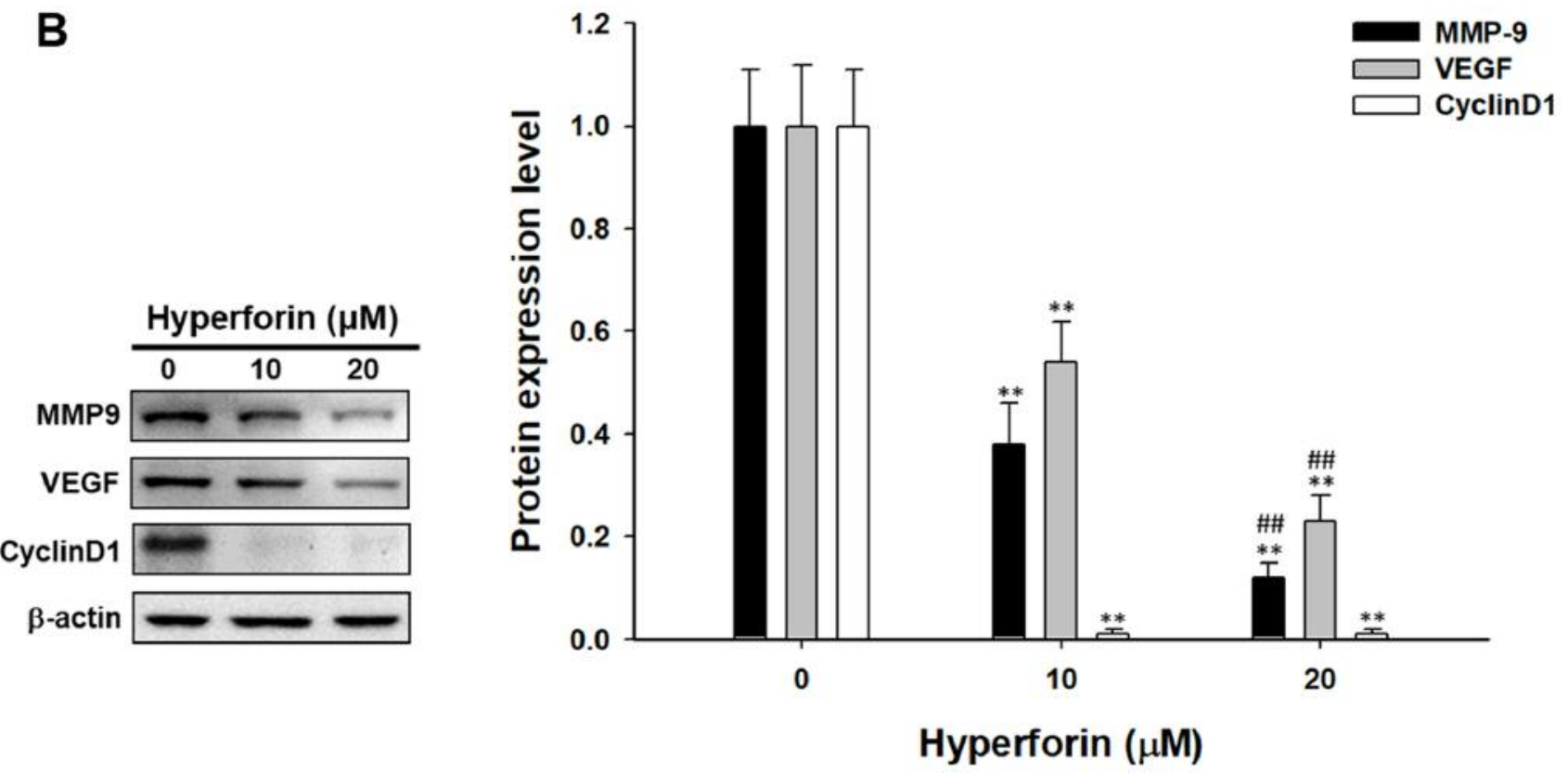

Figure 6. Continued 

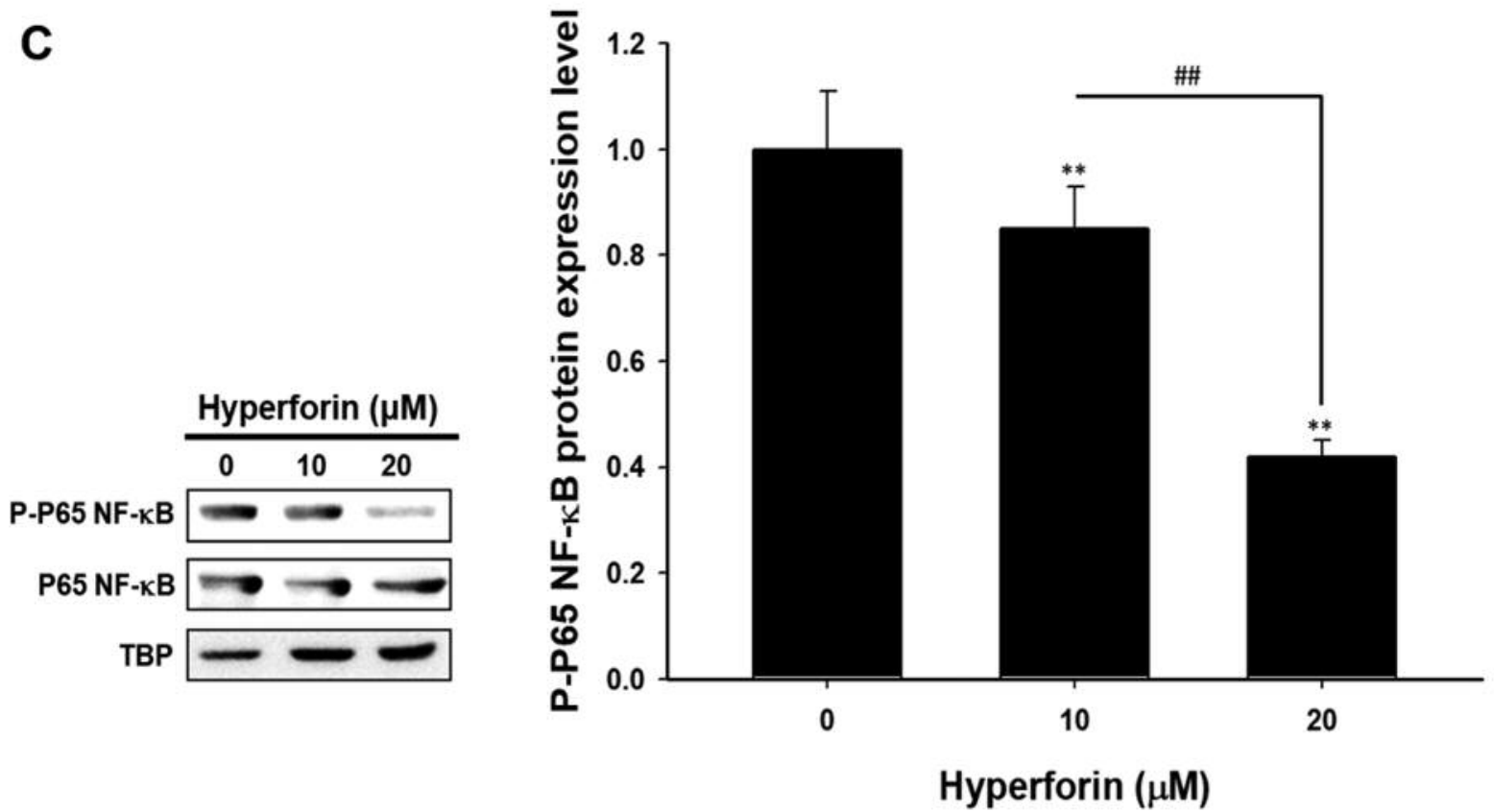

Figure 6. Hyperforin suppresses NF-kB mediated invasion ability and associated proteins expression of TSGH-8301 cells. TSGH-8301 cells were treated with 0, 10 and $20 \mu \mathrm{M}$ of hyperforin for $48 \mathrm{~h}$, and (A) cells were subsequently assayed by a transwell invasion assay. (B-C) The protein expression of MMP-9,VEGF, CyclinD1, phosphorylation and total P-65 NF-kB was assayed by western blot $(* * p<0.01$; treatments versus $0 \mu M$ hyperforin; ${ }^{\#} p<0.01$; treatments versus $10 \mu M$ hyperforin). Scale bars: $200 \mu \mathrm{m}$.

cancers (23). In addition, reduced expression of apoptotic proteins, such as Fas and Caspase- 3 is linked to poor outcome in patients with bladder cancer $(24,25)$. In our results we demonstrate that hyperforin significantly induces apoptosis and extrinsic/intrinsic apoptotic signaling (increases of activeFas, FasL, Caspase- 8 and loss of mitochondrial membrane potential) in TSGH-8301. It also increases the amount of reactive oxygen species (ROS) and calcium in cytoplasm and triggers apoptosis through DNA damage and endoplasmic reticulum (ER)-related stress $(26,27)$. We also found that hyperforin significantly induces accumulation of ROS and calcium in TSGH-8301 cells.

The oncogenic transcription factor NF-kB p50/p65, mediates tumor cell growth, survival, and invasion by inducing the expression of oncogenic proteins encoded by NF$\mathrm{kB}$ p65-dependent genes $(28,29)$. High expression of NF- $\mathrm{KB}$ p65 is observed and associated with poor prognosis in patients with MIBC (30). Protein levels of cyclin-D1, VEGF, MMP-9, XIAP, C-FLIP, and MCL-1 have been shown to be significantly decreased by specific NF-kB inhibitors in liver, lung, and bladder cancers $(10,11,13)$. In our results we showed that hyperforin significantly decreases the protein levels of NF-kB p65 (Ser 276) in TSGH-8301 cells.

In conclusion, hyperforin triggers apoptosis depending on the activation of extrinsic/intrinsic pathways and suppresses NF-kB-mediated cell survival and invasion in our bladder in vitro cancer model. We suggest that hyperforin may be recognized as a potential anticancer agent for the treatment of bladder cancer. Additionally, future in vivo experiments may also need to be further investigated for the efficacy of hyperforin as part of a treatment regime in living objects.

\section{Conflicts of Interest}

The Authors declare no competing financial interests regarding this study.

\section{Authors' Contributions}

YCL, KHL, JHH, JGC, ZLT and FTH performed the experiments and prepared the initial version of the paper. YCL, FTH and CHC designed the study, performed the literature review, and prepared the final versions of the paper.

\section{Acknowledgements}

The present study were supported by the Taipei Veterans General Hospital, Yuan-Shan Branch (grant numbers: YSVH-10702) and Chang Bing Show Chwan Memorial Hospital (grant numbers: BRD108010). 


\section{References}

1 Park JC, Citrin DE, Agarwal PK and Apolo AB: Multimodal management of muscle-invasive bladder cancer. Curr Probl Cancer 38: 80-108, 2014. PMID: 25087173. DOI: 10.1016/ j.currproblcancer.2014.06.001

2 Soria F and Shariat SF: Biomarkers for the prediction of oncologic outcomes in non-muscle invasive bladder cancer: State of affairs and new frontiers. Transl Androl Urol 7: S753S755, 2018. PMID: 30687617. DOI: 10.21037/tau.2018.08.10

3 Azevedo R, Ferreira JA, Peixoto A, Neves M, Sousa N, Lima A and Santos LL: Emerging antibody-based therapeutic strategies for bladder cancer: A systematic review. J Control Release 214: 40-61, 2015. PMID: 26196222. DOI: 10.1016/j.jconrel.2015.07.002

4 Zamora-Ros R, Sacerdote C, Ricceri F, Weiderpass E, Roswall N, Buckland G, St-Jules DE, Overvad K, Kyro C, Fagherazzi G, Kvaskoff M, Severi G, Chang-Claude J, Kaaks R, Nothlings U, Trichopoulou A, Naska A, Trichopoulos D, Palli D, Grioni S, Mattiello A, Tumino R, Gram IT, Engeset D, Huerta JM, Molina-Montes E, Arguelles M, Amiano P, Ardanaz E, Ericson U, Lindkvist B, Nilsson LM, Kiemeney LA, Ros M, Bueno-deMesquita HB, Peeters PH, Khaw KT, Wareham NJ, Knaze V, Romieu I, Scalbert A, Brennan P, Wark P, Vineis P, Riboli E and Gonzalez CA: Flavonoid and lignan intake in relation to bladder cancer risk in the european prospective investigation into cancer and nutrition (epic) study. Br J Cancer 111: 1870-1880, 2014. PMID: 25121955. DOI: 10.1038/bjc.2014.459

5 Lee DH, Kim SS, Seong S, Woo CR and Han JB: A case of metastatic bladder cancer in both lungs treated with korean medicine therapy alone. Case Rep Oncol 7: 534-540, 2014. PMID: 25232323. DOI: $10.1159 / 000365884$

6 Zanoli P: Role of hyperforin in the pharmacological activities of st. John's wort. CNS Drug Rev 10: 203-218, 2004. PMID: 15492771. DOI: 10.1111/j.1527-3458.2004.tb00022.x

7 Chiang IT, Chen WT, Tseng CW, Chen YC, Kuo YC, Chen BJ, Weng MC, Lin HJ and Wang WS: Hyperforin inhibits cell growth by inducing intrinsic and extrinsic apoptotic pathways in hepatocellular carcinoma cells. Anticancer Res 37: 161-167, 2017. PMID: 28011486. DOI: 10.21873/anticanres.11301

8 Chen WT, Chen YK, Lin SS and Hsu FT: Hyperforin suppresses tumor growth and nf-kappab-mediated anti-apoptotic and invasive potential of non-small cell lung cancer. Anticancer Res 38: 2161-2167, 2018. PMID: 29599335. DOI: 10.21873/ anticanres. 12457

9 Reis ST, Leite KR, Piovesan LF, Pontes-Junior J, Viana NI, Abe DK, Crippa A, Moura CM, Adonias SP, Srougi M and Dall'Oglio MF: Increased expression of mmp-9 and il-8 are correlated with poor prognosis of bladder cancer. BMC Urol 12: 18, 2012. PMID: 22695075. DOI: 10.1186/1471-2490-12-18

10 Chiang $\mathrm{CH}$, Chung JG and Hsu FT: Regorefenib induces extrinsic/intrinsic apoptosis and inhibits mapk/nf-kappabmodulated tumor progression in bladder cancer in vitro and in vivo. Environ Toxicol 34: 679-688, 2019. PMID: 30801954. DOI: $10.1002 /$ tox.22734

11 Tsai JJ, Pan PJ and Hsu FT: Regorafenib induces extrinsic and intrinsic apoptosis through inhibition of erk/nf-kappab activation in hepatocellular carcinoma cells. Oncol Rep 37: 1036-1044, 2017. PMID: 28000898. DOI: 10.3892/or.2016.5328

12 Krzyzowska M, Shestakov A, Eriksson K and Chiodi F: Role of fas/fasl in regulation of inflammation in vaginal tissue during hsv-2 infection. Cell Death Dis 2: e132, 2011. PMID: 21412278. DOI: $10.1038 /$ cddis.2011.14

13 Chen WT, Hsu FT and Liu YC: Fluoxetine induces apoptosis through extrinsic/intrinsic pathways and inhibits erk/nf-kappabmodulated anti-apoptotic and invasive potential in hepatocellular carcinoma cells in vitro. Int J Mol Sci 20, 2019. PMID: 30754643. DOI: 10.3390/ijms20030757

14 Hsia TC, Huang YP, Jiang YW, Chen HY, Cheng ZY, Hsiao YT, Chen CY, Peng SF, Chueh FS, Chou YC and Chung JG: Phenethyl isothiocyanate induces apoptotic cell death through the mitochondria-dependent pathway in gefitinib-resistant nci$\mathrm{h} 460$ human lung cancer cells in vitro. Anticancer Res 38: 21372147, 2018. PMID: 29599332. DOI: 10.21873/anticanres.12454

15 Hsu FT, Sun CC, Wu CH, Lee YJ, Chiang CH and Wang WS: Regorafenib induces apoptosis and inhibits metastatic potential of human bladder carcinoma cells. Anticancer Res 37: 49194926, 2017. PMID: 28870913. DOI: 10.21873/anticanres.11901

$16 \mathrm{Wu}$ JY, Lin SS, Hsu FT and Chung JG: Fluoxetine inhibits DNA repair and nf-kb-modulated metastatic potential in non-small cell lung cancer. Anticancer Res 38: 5201-5210, 2018. PMID: 30194168. DOI: 10.21873 /anticanres.12843

17 Kopparapu PK, Boorjian SA, Robinson BD, Downes M, Gudas LJ, Mongan NP and Persson JL: Expression of cyclin d1 and its association with disease characteristics in bladder cancer. Anticancer Res 33: 5235-5242, 2013. PMID: 24324055.

18 Kopparapu PK, Boorjian SA, Robinson BD, Downes M, Gudas LJ, Mongan NP and Persson JL: Expression of vegf and its receptors vegfr1/vegfr2 is associated with invasiveness of bladder cancer. Anticancer Res 33: 2381-2390, 2013. PMID: 23749886. DOI: $10.1002 /$ jcb. 21707

19 Plati J, Bucur O and Khosravi-Far R: Dysregulation of apoptotic signaling in cancer: Molecular mechanisms and therapeutic opportunities. J Cell Biochem 104: 1124-1149, 2008. PMID: 18459149.

20 Fernald $\mathrm{K}$ and Kurokawa M: Evading apoptosis in cancer. Trends Cell Biol 23: 620-633, 2013. PMID: 23958396. DOI: 10.1016/j.tcb.2013.07.006

21 Drayton RM and Catto JW: Molecular mechanisms of cisplatin resistance in bladder cancer. Expert Rev Anticancer Ther 12(2): 271-281, 2012. PMID: 22316374. DOI: 10.1586/era.11.201

22 Lee S, Yoon CY, Byun SS, Lee E and Lee SE: The role of c-flip in cisplatin resistance of human bladder cancer cells. J Urol 189: 2327-2334, 2013. PMID: 23313194. DOI: 10.1016/j.juro.2013. 01.003

$23 \mathrm{Li} \mathrm{H}-\mathrm{T}$, Duymich CE, Weisenberger DJ and Liang G: Genetic and epigenetic alterations in bladder cancer. Int Neurourol J 20: S84-S94, 2016. PMID: 27915480. DOI: 10.5213/inj.16327 52.376

24 Yamana K, Bilim V, Hara N, Kasahara T, Itoi T, Maruyama R, Nishiyama T, Takahashi K and Tomita Y: Prognostic impact of fas/cd95/apo-1 in urothelial cancers: Decreased expression of fas is associated with disease progression. Br J Cancer 93: 544-551, 2005. PMID: 16091761. DOI: 10.1038/sj.bjc.6602732

25 Wang J, Zhang X, Wei P, Zhang J, Niu Y, Kang N, Zhang Y, Zhang $\mathrm{W}$ and Xing N: Livin, survivin and caspase 3 as early recurrence markers in non-muscle-invasive bladder cancer. World J Urol 32: 1477-1484, 2014. PMID: 24595485. DOI: 10.1007/s00345-014-1246-0

26 Redza-Dutordoir $\mathrm{M}$ and Averill-Bates DA: Activation of apoptosis signalling pathways by reactive oxygen species. 
Biochim Biophys Acta 1863: 2977-2992, 2016. PMID: 27646 922. DOI: $10.1016 /$ j.bbamcr.2016.09.012

27 Wang WH, Chiang IT, Ding K, Chung JG, Lin WJ, Lin SS and Hwang JJ: Curcumin-induced apoptosis in human hepatocellular carcinoma j5 cells: Critical role of $\mathrm{ca}(+2)$-dependent pathway. Evid Based Complement Alternat Med 2012: 512907, 2012. PMID: 22606206. DOI: 10.1155/2012/512907

28 Weng MC, Wang MH, Tsai JJ, Kuo YC, Liu YC, Hsu FT and Wang HE: Regorafenib inhibits tumor progression through suppression of erk/nf-kappab activation in hepatocellular carcinoma bearing mice. Biosci Rep 38, 2018. PMID: 29535278. DOI: 10.1042/BSR20171264

29 Liu YC, Chiang IT, Hsu FT and Hwang JJ: Using nf-kappab as a molecular target for theranostics in radiation oncology research. Expert Rev Mol Diagn 12: 139-146, 2012. PMID: 22369374. DOI: $10.1586 / \mathrm{erm} .12 .2$
30 Inoue S, Ide H, Mizushima T, Jiang G, Netto GJ, Gotoh $\mathrm{M}$ and Miyamoto $\mathrm{H}$ : Nuclear factor-kappab promotes urothelial tumorigenesis and cancer progression via cooperation with androgen receptor signaling. Mol Cancer Ther 17: 1303-1314, 2018. PMID: 29592878. DOI: 10.1158/1535-7163.MCT-17-0786

Received July 11, 2019

Revised August 1, 2019

Accepted August 2, 2019 